\title{
STUDIES ON THE MORBIDITY OF FOREIGN VISITORS TO A CERTAIN COMPANY IN JAPAN
}

\author{
Etsushi Okumura ${ }^{1}$, Masuyo Nakai ${ }^{2}$, Hirofumi Miyoshi ${ }^{2}$, \\ Yasuhisa Yoshida ${ }^{3}$ and Shuzo Toyota ${ }^{3}$ \\ Received for publication 11 October 1977
}

\begin{abstract}
Recent papers suggested that as the result of the increase of Japanese travellers abroad, number of patients affected with imported tropical disease increased every year. This fact also implies that foreign visitors are bringing tropical disease into Japan. Therefore, we have conducted a survey of foreign visitors who visited Matsushita Electric Co. Ltd. for the purpose of technical training for short periods from 1972 to 1976 , studying the possibility of invasion of tropical diseases by interview and on medical records. The results obtained were as follows:

1. Of total 532 visitors, 485 were from tropical regions and 47 from other countries, and the morbidity rates indicated 20.2 per cent and 29.8 per cent respectively in the observation period of one month following their arrival.

2. Fortunately no tropical diseases such as malaria, filariasis, dengue fever and cholera were found so far.

3. Two cases, a Malaysian with Tenia saginata and an Iranian with orchitis following mumps which had affected him for some time before their arrival, were cured.

4. Many visitors from tropical regions were easily affected with common cold within a few days after their arrival, especially in the fall and winter season, as compared with those from Europe and North America.

5. A thorough check-up routine of the Japanese returnees and foreign visitors to Japan and general practitioners' good understanding of the imported tropical diseases are mandatory for the prevention of tropical diseases in the future.
\end{abstract}

\section{INTRODUCTION}

As the number of Japanese travellers abroad increased recently, patients of imported tropical diseases also increased in number year after year. These imported tropical diseases are found among travellers who were affected with the native diseases and felt sick after their return home. Besides the increase of Japanese travellers abroad, gradual increase of foreign visitors to Japan is also found as a new tendency, as cultural exchange with foreign countries are being encouraged. What has to be taken into consideration with this tendency is that there is a big possibility for people from tropical areas of bringing in some tropical diseases.

Actually, according to the questionaire survey of imported malaria by Nakabayashi et al. (1975), 14 out of 155 visitors from abroad were reported as affected

1 Department of the Second Internal Medicine, 2 Department of Microbiology, 3 Department of Hygiene and Public Health, Osaka Medical College, Osaka 569, Japan. 
patients. This fact should imply a number of problems of counterplan against imported tropical diseases. The following is a report of our study on foreign visitors in Japan, for the purpose of studying morbidity of imported tropical diseases among alien people.

\section{Subjects And Methods}

The subjects of the study were 532 foreign employees of overseas branch offices, factories and sales offices of Matsushita Electric Co. Ltd., who visited Japan from April 1972 to March 1976 from 33 different countries. The classification of regions follows that of the report by Sassa et al. (1976) as shown in Figure 1. They are based on the imported tropical disease distribution chart, A; Africa, B; Asia, C; Pacific Islands, D; Middle and South America and E; Caribbean Islands.

In addition, Africa is divided into subareas such as $\mathrm{A}_{1}$; Middle Western district, $\mathrm{A}_{2}$; Middle East and neighbouring islands district, $\mathrm{A}_{3}$; North and Pacific Islands district, $\mathrm{A}_{4}$; North Eastern district and $\mathrm{A}_{5}$; Southern district. Asia is also divided into $\mathrm{B}_{1}$; Eastern Mediteranean Sea and Middle East Asia district, $\mathrm{B}_{2}$; India and Pakistan district and $\mathrm{B}_{3}$; South East Asian district.

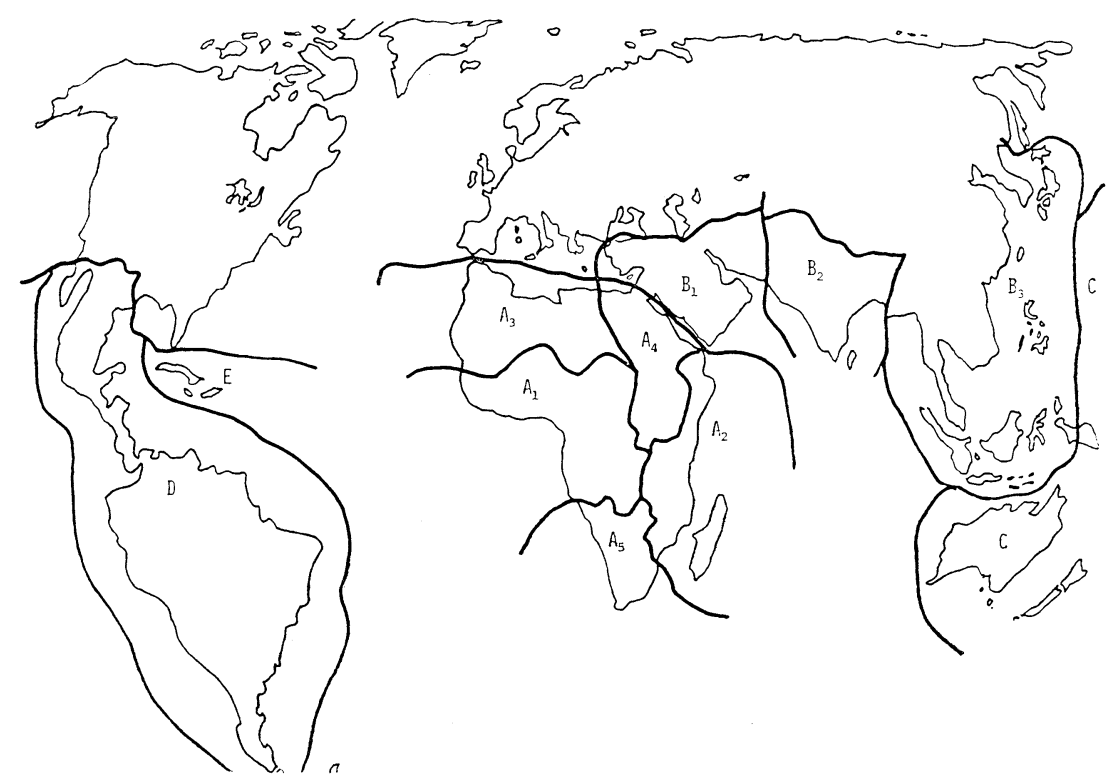

Figure 1 Classification of tropical regions.

The methods of the study were as follows; Examined were people who came for a check-up to the company clinic attached to Matsushita Overseas Training Center, complaining some disorder with in a month after their arrival from the above-mentioned region during the above-mentioned period. All 112 patients were given as much examination as the clinic could offer for the detection of imported tropical 
diseases. All 112 patients were examined on their urine. People complaining high fever were given Giemsa staining test of their smear sampling of blood. People complaining diarrhoea were offered microscopic examination for parasites and protozoa and also offered cultural examination for pathogenous microorganisms. Matsushita Overseas Training Center is located in Hirakata City, providing training and housing to foreign trainees in Japan.

\section{Results}

1. Regions and countries of foreign visitors and their morbidity rate

All 19 visitors out of A region were from the United Republic of Tanzania from 1972 to 1976. Six patients were found among them and the morbidity rate was 31.6 per cent. Six visitors from $\mathrm{C}$ region were all Australians and none was found sick. Of 53 visitors from $\mathrm{D}$ region, nine patients were sick and the rate was 17 per cent. The breakdown of $\mathrm{D}$ region is as follows; one out of nine visitors from Mexico was sick (11.1\%), none of two visitors from El Salvador was sick, two of 10 visitors from Costa Rica were sick $(20 \%)$, one of two visitors from Panama was sick $(50 \%)$, one of four visitors from Venezuela was sick $(25 \%)$, two of 16 visitors from Peru were sick $(12.5 \%)$, two of 10 visitors from Brazil were sick $(20 \%)$. Nineteen visitors from $\mathrm{E}$ region were only from Puerto Rico and three were found sick $(15.8 \%)$ (Table 1).

Table 1 Incidence rate in $\mathrm{A}, \mathrm{C}, \mathrm{D}$ and $\mathrm{E}$ regions

\begin{tabular}{|c|c|c|c|c|c|c|c|c|c|}
\hline \multirow{2}{*}{ Group } & \multirow{2}{*}{ Country } & \multicolumn{5}{|c|}{ Year } & \multirow{2}{*}{ Total } & \multirow{2}{*}{$\%$} & \multirow{2}{*}{ Group-total } \\
\hline & & 1972 & 1973 & 1974 & 1975 & 1976 & & & \\
\hline $\mathrm{A}_{2}$ & $\begin{array}{l}\text { United } \\
\text { Republic of } \\
\text { Tanzania }\end{array}$ & $1 / 3$ & $1 / 3$ & $1 / 4$ & $3 / 8$ & $0 / 1$ & $6 / 19$ & $31.6 \%$ & $6 / 19(31.6 \%)$ \\
\hline $\mathrm{C}$ & Australia & $0 / 0$ & $0 / 2$ & $0 / 2$ & $0 / 2$ & $0 / 0$ & $0 / 6$ & $0 \%$ & $0 / 6(0 \%)$ \\
\hline $\mathrm{D}$ & $\begin{array}{l}\text { Mexico } \\
\text { El Salvador } \\
\text { Costa Rica } \\
\text { Panama } \\
\text { Venezuela } \\
\text { Peru } \\
\text { Brazil }\end{array}$ & $\begin{array}{l}1 / 3 \\
0 / 0 \\
0 / 3 \\
0 / 0 \\
0 / 1 \\
0 / 3 \\
0 / 2\end{array}$ & $\begin{array}{l}0 / 3 \\
0 / 0 \\
2 / 6 \\
0 / 1 \\
0 / 1 \\
0 / 3 \\
0 / 2\end{array}$ & $\begin{array}{l}0 / 2 \\
0 / 0 \\
0 / 1 \\
1 / 1 \\
1 / 2 \\
2 / 7 \\
1 / 5\end{array}$ & $\begin{array}{l}0 / 0 \\
0 / 1 \\
0 / 0 \\
0 / 0 \\
0 / 0 \\
0 / 3 \\
1 / 1\end{array}$ & $\begin{array}{l}0 / 1 \\
0 / 1 \\
0 / 0 \\
0 / 0 \\
0 / 0 \\
0 / 0 \\
0 / 0\end{array}$ & $\begin{array}{r}1 / 9 \\
0 / 2 \\
2 / 10 \\
1 / 2 \\
1 / 4 \\
2 / 16 \\
2 / 10\end{array}$ & $\begin{array}{r}11.1 \% \\
0 \% \\
20.0 \% \\
50.0 \% \\
25.0 \% \\
12.5 \% \\
20.0 \%\end{array}$ & $9 / 53(17.0 \%)$ \\
\hline $\mathrm{E}$ & Puerto Rico & $3 / 12$ & $0 / 6$ & $0 / 0$ & $0 / 1$ & $0 / 0$ & $3 / 19$ & $15.8 \%$ & $3 / 19(15.8 \%)$ \\
\hline
\end{tabular}

Following are the breakdown of $\mathrm{B}$ region. In $\mathrm{B}_{1}$ district, one of four visitors from Iran $(25 \%)$ and one visitor from the United Arab Emirates (100\%) were found sick. In total, two of five were sick $(40 \%)$. In $\mathrm{B}_{2}$ district, three out of nine visitors from India were sick $(33.3 \%)$. In $\mathrm{B}_{3}$ district, found sick were nine out of 24 vistiors from the Republic of Korea $(37.5 \%), 15$ out of 100 from the Republic of China $(15 \%)$, six out of 35 from the Philippines $(17.1 \%$ ), five out of 37 from Indonesia $(13.5 \%)$, two from Hong Kong $(100 \%)$, one out of nine from Vietnam $(11.1 \%), 13$ out of 26 from Thailand $(50 \%), 21$ out of 104 from Malaysia $(20.2 \%)$ 
Table 2 Incidence rate in $\mathrm{B}$ region

\begin{tabular}{|c|c|c|c|c|c|c|c|c|c|}
\hline \multirow{2}{*}{ Group } & \multirow{2}{*}{ Country } & \multicolumn{5}{|c|}{ Year } & \multirow{2}{*}{ Total } & \multirow{2}{*}{$\%$} & \multirow{2}{*}{ Group-total } \\
\hline & & 1972 & 1973 & 1974 & 1975 & 1976 & & & \\
\hline \multirow[b]{2}{*}{$\mathrm{B}_{1}$} & Iran & $0 / 0$ & $0 / 2$ & $0 / 0$ & $1 / 2$ & $0 / 0$ & $1 / 4$ & $25.0 \%$ & \multirow[b]{2}{*}{$2 / 5(40.0 \%)$} \\
\hline & $\begin{array}{c}\text { United Arab } \\
\text { Emirates }\end{array}$ & $0 / 0$ & $0 / 0$ & $0 / 0$ & $0 / 0$ & $1 / 1$ & $1 / 1$ & $100 \%$ & \\
\hline $\mathrm{B}_{2}$ & India & $0 / 0$ & $1 / 1$ & $2 / 6$ & $0 / 2$ & $0 / 0$ & $3 / 9$ & $33.3 \%$ & $3 / 9(33.3 \%)$ \\
\hline \multirow{9}{*}{$\mathrm{B}_{3}$} & $\begin{array}{l}\text { Republic of } \\
\text { Korea }\end{array}$ & $0 / 0$ & $4 / 12$ & $1 / 1$ & $4 / 11$ & $0 / 0$ & $9 / 24$ & $37.5 \%$ & \multirow{9}{*}{$75 / 374(20.1 \%)$} \\
\hline & $\begin{array}{l}\text { Republic of } \\
\text { China }\end{array}$ & $2 / 11$ & $4 / 23$ & $3 / 25$ & $2 / 21$ & $4 / 20$ & $15 / 100$ & $15.0 \%$ & \\
\hline & Philippines & $1 / 6$ & $2 / 10$ & $1 / 7$ & $2 / 10$ & $0 / 2$ & $6 / 35$ & $17.1 \%$ & \\
\hline & Indonesia & $1 / 3$ & $2 / 19$ & $1 / 13$ & $1 / 3$ & $0 / 0$ & $5 / 37$ & $13.5 \%$ & \\
\hline & Hong Kong & $0 / 0$ & $0 / 0$ & $1 / 1$ & $1 / 1$ & $0 / 0$ & $2 / 2$ & $100 \%$ & \\
\hline & Vietnam & $0 / 0$ & $0 / 3$ & $0 / 5$ & $1 / 1$ & $0 / 0$ & $1 / 9$ & $11.1 \%$ & \\
\hline & Thailand & $3 / 5$ & $0 / 2$ & $3 / 6$ & $7 / 11$ & $0 / 2$ & $13 / 26$ & $50.0 \%$ & \\
\hline & Malaysia & $5 / 22$ & $7 / 32$ & $6 / 33$ & $2 / 12$ & $1 / 5$ & $21 / 104$ & $20.2 \%$ & \\
\hline & Singapore & $2 / 30$ & $0 / 2$ & $1 / 4$ & $0 / 0$ & $0 / 1$ & $3 / 37$ & $8.1 \%$ & \\
\hline
\end{tabular}

and three out of 37 from Singapore (8.1\%). Seventy-five of all 374 visitors from $\mathrm{B}_{3}$ district were found sick and its incidence rate was 20.1 per cent (Table 2).

Forty-seven forigners who came from other regions showed following results. In Europe, one out of three visitors from Spain (33.3\%), five out of 12 from West Germany $(41.7 \%)$, one out of four from Netherland $(25 \%)$ and one out of three from Denmark $(33.3 \%)$ were found sick. Three Belgian and three British were healthy in the observation period. Each one who came from Sweden, Switzerland and Poland were sick. In North America, two out of five visitors from the United States of America and one out of 11 from Canada were found sick. Fourteen patients were found out of 47 visitors from other regions $(29.8 \%$ ) (Table 3 ).

Summerizing the above results, the number of patients out of 485 visitors from 22 countries in the tropical regions of A, B, C, D and E was 98, and its incidence rate was 20.2 per cent, while that of 47 visitors from 11 countries in other region was

Table 3 Incidence rate in other region

\begin{tabular}{l|rrrrr|r|r|r}
\hline \multirow{2}{*}{ Country } & \multicolumn{5}{|c|}{ Year } & Total & $\%$ & Group-total \\
\cline { 2 - 5 } & 1972 & 1973 & 1974 & 1975 & 1976 & & \\
\hline Spain & $0 / 0$ & $0 / 0$ & $0 / 1$ & $1 / 2$ & $0 / 0$ & $1 / 3$ & $33.3 \%$ & \\
West Germany & $2 / 3$ & $1 / 5$ & $1 / 2$ & $1 / 2$ & $0 / 0$ & $5 / 12$ & $41.7 \%$ & \\
Belgium & $0 / 0$ & $0 / 0$ & $0 / 0$ & $0 / 1$ & $0 / 2$ & $0 / 3$ & $0 \%$ & \\
Netherland & $0 / 1$ & $0 / 1$ & $0 / 1$ & $1 / 1$ & $0 / 0$ & $1 / 4$ & $25.0 \%$ & \\
United Kingdom & $0 / 0$ & $0 / 0$ & $0 / 0$ & $0 / 1$ & $0 / 2$ & $0 / 3$ & $0 \%$ & \multirow{2}{*}{$14 / 47(29.8 \%)$} \\
Denmark & $1 / 2$ & $0 / 0$ & $0 / 0$ & $0 / 1$ & $0 / 0$ & $1 / 3$ & $33.3 \%$ & \\
Sweden & $0 / 0$ & $0 / 0$ & $0 / 0$ & $0 / 0$ & $1 / 1$ & $1 / 1$ & $100 \%$ & \\
Switzerland & $0 / 0$ & $0 / 0$ & $1 / 1$ & $0 / 0$ & $0 / 0$ & $1 / 1$ & $100 \%$ & \\
Poland & $1 / 1$ & $0 / 0$ & $0 / 0$ & $0 / 0$ & $0 / 0$ & $1 / 1$ & $100 \%$ & \\
United States & $0 / 0$ & $0 / 3$ & $0 / 0$ & $2 / 3$ & $0 / 2$ & $2 / 5$ & $40.0 \%$ & \\
of America & & & & & & & & \\
Canada & $0 / 1$ & $0 / 2$ & $1 / 4$ & $0 / 2$ & $0 / 2$ & $1 / 11$ & $9.1 \%$ & \\
\hline
\end{tabular}


14 and its incidence rate was 29.8 per cent. The total number of patients out of all 532 visitors from 33 countries was 112 and its incidence rate was 21.1 per cent. As seen above, no paticular region, district or country showed specific characteristics in its incidence rate (Table 4 ).

Table 4 Incidence rate in all regions

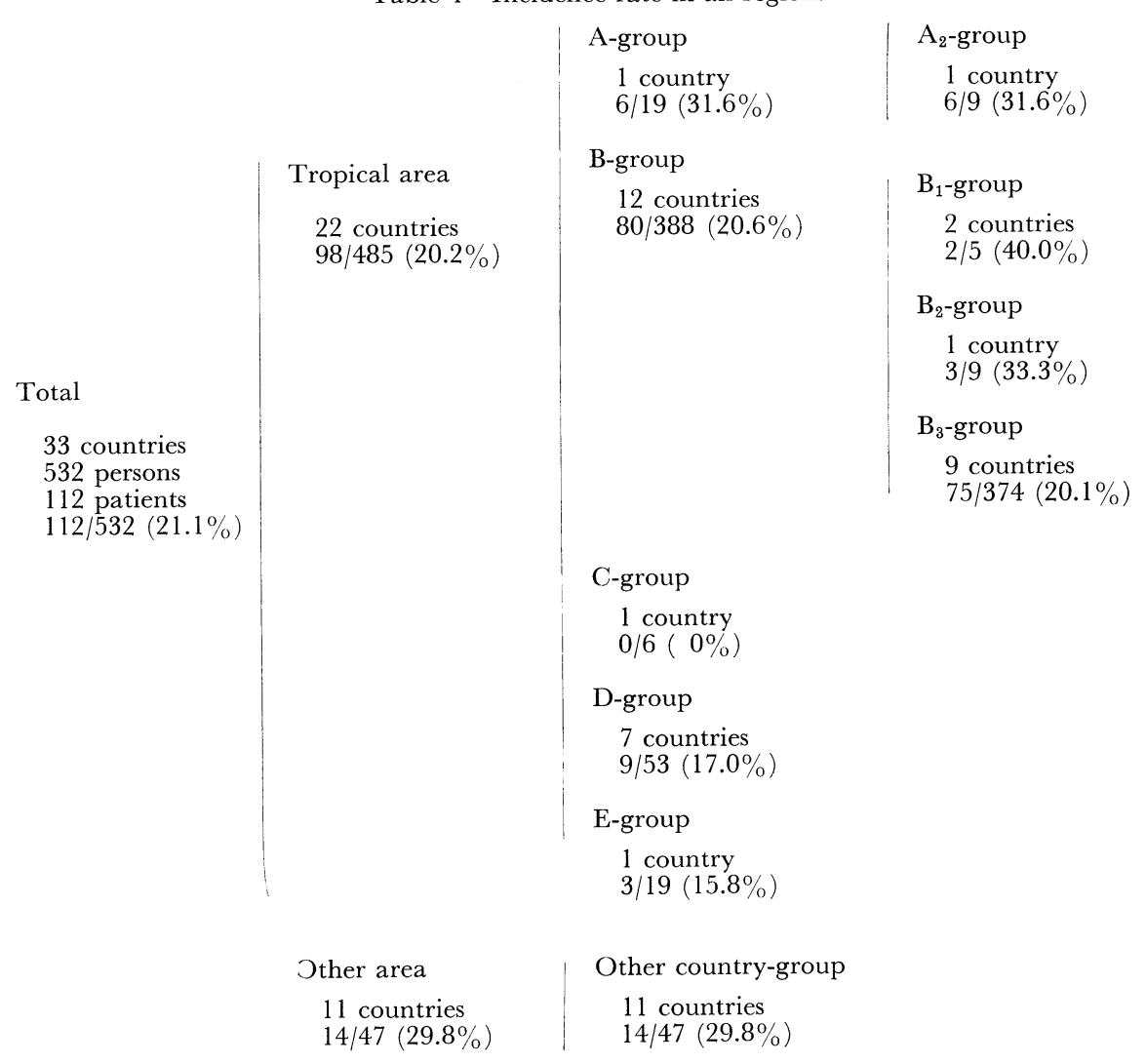

\section{Classification of diseases}

Out of six patients from Tanzania in $\mathrm{A}_{2}$ district, A region, five were with common cold and one with colitis. In $\mathrm{D}$ region, one Mexican was with gastritis, one Costa Rican was with common cold and the other with atopic dermatitis of arms and legs, one Brazilian, one Panaman, one Venezuelan and two Peruvian were with common cold, and one Brazilian with colitis. All three Puerto Rican patients were with common cold (Table 5).

A 31-years-old Iranian from $\mathrm{B}_{1}$ district, $\mathrm{B}$ region, flew to Japan, already suffering from remittant fever since three days before his arrival. On the arrival at Osaka Airport, although he felt fatigue and had fever associated with left parotid swelling, he passed the quarantine inspection, and his fever went down to $37.5 \mathrm{C}$ after a rest on the following day. On the next day (the 3rd day after arrival), the fever went 
Table 5 Classification of sickness in each country

A, B, C, D, E-Group

$\mathrm{A}_{2} \quad$ United Republic of Tanzania Common cold $5(26.3 \%)$

$(6 / 19)$ Colitis 1

$\mathrm{B}_{1} \quad$ Iran $(1 / 4)$ Orchitis 1

United Arab Emirates (1/1) Common cold $1(100 \%)$

$\mathrm{B}_{2} \quad$ India $(3 / 9)$

Common cold $1(11.1 \%)$

Urticaria 1

Angular stomatitis 1

$\mathbf{B}_{3} \quad$ Republic of Korea $\quad(9 / 24)$

Common cold $5(20.8 \%)$

Motion sickness

Menorrhalgia 1

Aphtha 1

Neurosis 1

Republic of China $\quad(15 / 100)$

Common cold $12(12.0 \%)$

Colitis 3

Philippines (6/35)

Common cold $6(17.1 \%)$

Indonesia $(5 / 37)$

Common cold $5(13.5 \%)$

Hong Kong (2/2)

Common cold $1(50.0 \%)$

Gastritis 1

Vietnam $(1 / 9)$

Asthma 1

Thailand (13/26)

Common cold $8(30.8 \%)$

Conjunctivitis 1

Colitis 2

Gastritis

Malaysia (21/104)

Common cold $19(18.3 \%)$

Gastritis 1

Tapeworm infestation 1

Singapore $\quad(3 / 37)$

Common cold $2(5.4 \%)$

Urticaria 1

C Australia (0/6)

D Mexico (1/9)

Gastritis 1
El Salvador $(0 / 2)$

Costa Rica (2/10)

Common cold $1(10.0 \%)$

Dermatitis 1

Panama (1/2)

Common cold $1(50.0 \%)$

Venezuela (1/4)

Common cold $1(25.0 \%)$

Peru (2/16)

Common cold $2(12.5 \%)$

Brazil (2/10)

Common cold $1(10.0 \%)$

Colitis 1

E Puerto Rico (3/13)

Common cold $3(15.8 \%)$

Other country-Group

Spain (1/3)

Renal calculus 1

West Germany (5/12)

Urethritis 1

Otitis externa 1

Callosity 1

Trauma 2

Belgium (0/3)

Netherland (1/4)

Gastritis

United Kingdom (0/3)

Denmark (1/3)

Common cold $1(33.3 \%)$

Sweden (1/1)

Urticaria 1

Switzerland (1/1)

Panaritium 1

Poland (1/1)

Common cold $1(100 \%)$

United States of America (2/5)

Colitis 1

Otitis media 1

Canada (1/11)

Common cold $1(9.1 \%)$ 
up again to $39 \mathrm{C}$. An antifebrile and an ice compress of left cheek did not calm it down and on the fourth day after arrival (the 7th sick day), he suffered from orchitis on both sides. Protozoa was not proved by smear sampling of blood. Exanthema and digestive disorder were not found either. Moreover, even after detailed check-up, none of typhoid fever, smallpox, dengue fever, or orchitis usually following malaria was found. Therefore, the case was diagnosed as acute orchitis following acute parotitis, and the patient was hospitalized in Hirakata Municipal Hospital for five days.

One from the United Arab Emirates had common cold. Three Indians from $\mathrm{B}_{2}$ district had urticalia, angular stomatitis and common cold respectively. Among Korean patients from $\mathrm{B}_{3}$ district, one was homesick, one with menorrhalgia, one with aphtha, one with neurosis and five others with common cold. Three Taiwanese were with colitis, 12 others were with common cold, one Singaporean was with urticaria and two others had common cold. Six Philippines and five Indonesians were with common cold. One Chinese from Hong Kong was with gastritis and the other was with common cold. One Vietnamese was with atopic asthma and the antigen was suspected as house dust according to anamnesis and intractutaneous test. One Thai was with colitis, one with conjuctivitis, one with gastritis, and eight others were with common cold. One Malaysian was with gastritis, 19 with common cold and with one Tenia saginata. This patient caused by Tenia saginata was a 27 -yearsold man and had repeated diarrhoea for one month. He had a habit of eating raw beef. He felt uneasy around the anus 3 days after his arrival to Japan. After the examination, Tenia saginata was suspected, he was administered helminthic, 10 grams of Extractum filicis and 5 grams of magnesium sulfate in hunger, and 4 meters of helminth was excreted and no diarrhoea was found after that.

In other regions, one Spanish man suffered from right nephrolith and excreted sesame size of calculi after a drug therapy in 18 days of hospitalization. One patient from West Germany was with urethritis, one with right otitis externa, one with callosity and two with trauma. One from Denmark, one from Canada and one from Poland were with common cold, and one Dutch was with gastritis, one Swiss with panaritium, one American with right otitis media and another American with colitis. Eight colitis patients of one Tanzanian, one Brazilian, three Taiwanese, two Thais and one American were consulted with a complaint of one to three times of diarrhoea a day. The examination of parasites of stool and culture of pathogenic microorganisms were all negative (TCBS and SS medium was applied for stool culture) (Table 5).

As mentioned above, no significant relationship was found between the country and patient sample according to these classification of region-countries and patient sample. Among these patients, common cold was found in 77 cases. More people from A, B, C, D and E regions were found with common cold (74 out of $485 ; 15.3 \%$ ) than those from North America and Europe (3 out of $47 ; 6.3 \%$ ). According to the study of onset of common cold in these patients, most visitors from tropical zone were affected within a week of the arrival and the peak was the third day after their arrival (Fig. 2). Fortunately, every patient recovered by medication, mainly antipyretics and antihistamine, and good rest. Two out of 12 Taiwanese, three out of 19 Malaysians, two out of eight Thais, one out of five Indonesians, one out of 
five Tanzanians, one Venezueran who were affected with common cold had fever of at least $37.5 \mathrm{C}$ to $38.5 \mathrm{C}$. On the patients who were suspected to have had malaria, smear sampling of blood was made, and Giemsa staining test was performed. However, there was found no malaria protozoa shwoing ringstage, segmenter and gametocyte. Therefore, all patients were diagnosed as common cold. Tests for albuminuria and urine urobilinogen did not reveal any significant change.

Table 6 indicates monthly statistics of onset of common cold, in which most of the patients were found in the fall and winter. The upper row indicates the number of patients and the lower the number of foreign visitors in each month. This shows apparently higher morbidity rate of the visitors from tropical zone than those from Europe and North America.

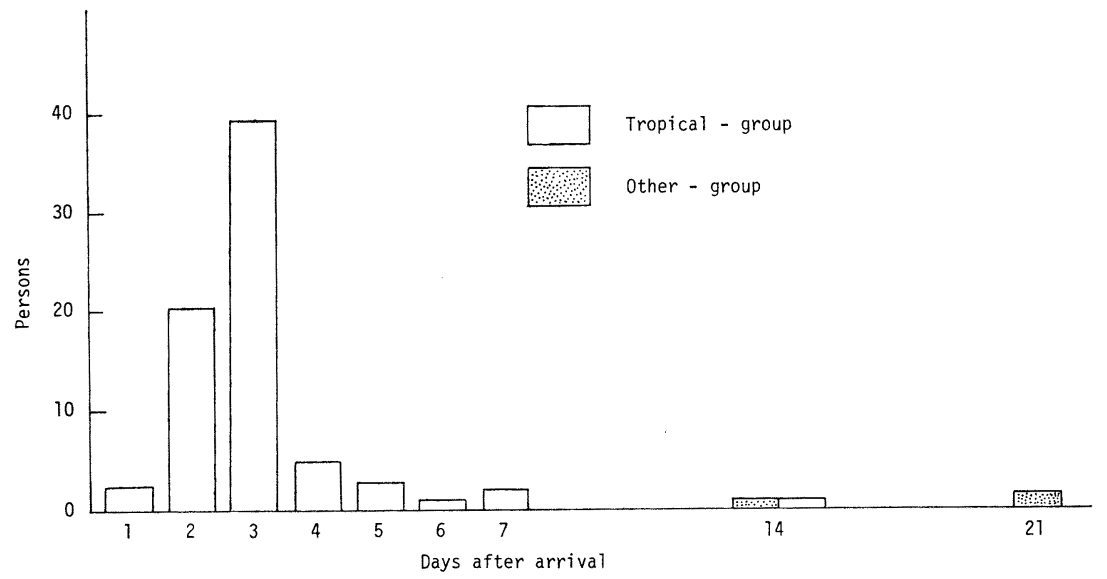

Figure 2 Number of day to onset of common cold after the arrival.

Table 6 Number of total visitors and common cold patients in each month for 5 years

\begin{tabular}{|c|c|c|c|c|c|c|c|c|c|c|c|c|c|}
\hline \multirow[b]{2}{*}{ Group } & \multirow{2}{*}{$\begin{array}{c}\text { Patients } \\
\text { and visitors }\end{array}$} & \multicolumn{12}{|c|}{ Month } \\
\hline & & Jan. & Feb. & Mar. & Apr & May & Jun. & Jul. & Aug. & Sep. & Oct. & Nov. & . Dec. \\
\hline \multirow{3}{*}{$\begin{array}{l}\mathrm{A}, \mathrm{B}, \mathrm{C}, \mathrm{D} \text { and } \\
\mathrm{E} \text { group }\end{array}$} & Common & 6 & 6 & 6 & 4 & 7 & 0 & 0 & 0 & 2 & 18 & 20 & 5 \\
\hline & $\begin{array}{c}\text { cold patients } \\
(\%)\end{array}$ & 22.2 & 24.0 & 9.4 & 6.3 & 11.3 & 0 & 0 & 0 & 1.2 & 10.3 & 13.5 & 6.3 \\
\hline & Total visitors & 27 & 25 & 64 & 64 & 62 & 68 & 75 & 127 & 166 & 174 & 148 & 80 \\
\hline \multirow{3}{*}{$\begin{array}{l}\text { Other country } \\
\text { group }\end{array}$} & Common & 0 & 0 & 1 & 0 & 0 & 0 & 0 & 0 & 0 & 1 & 1 & 1 \\
\hline & $\begin{array}{c}\text { cold patients } \\
(\%)\end{array}$ & 0 & 0 & 10.0 & 0 & 0 & 0 & 0 & 0 & 0 & 6.3 & 10.0 & 20.0 \\
\hline & Total visitors & 7 & 5 & 10 & 5 & 4 & 2 & 3 & 3 & 8 & 16 & 10 & 5 \\
\hline
\end{tabular}

\section{Discussion}

Not only sea men returning from abroad, but also people coming back from abroad and visitors to Japan by air are increasing tremendously in number, owing to increased overseas activities such as sightseeing, business trip, trade, academic 
research and study, technical aid and enterprises; more than 10,000 people are coming into Japan everyday through both Tokyo and Osaka airports.

These people usually do not have enough knowledge on prevention and therapy for tropical diseases. Their information is so limited that they get easily affected and some of them died as reported by Ebisawa et al. (1973). Imported tropical diseases found after the return are mainly malaria as reported by Ebisawa et al. (1969), Tsubura et al. (1973), Ebisawa et al. (1973), Yamaguchi et al. (1973) and Ebisawa et al. (1975).

Ebisawa et al. (1973) reported a detailed summerization of 73 patients found in 8 years from 1966 to 1973 . According to this report, most of the patients had $P l$. vivax, $P l$. falciparum and others had with $P l$. ovale or $P l$. malariae and were obliged to return home. Diseases other than malaria are also imported. They are nematodiasis, as reported by Kamegai et al. (1976), smallpox from Bangladesh, which was fortunately prevented from the 2nd affection in Japan by an appropriate protection at quarantine as reportcd by Hino et al. (1973), and dengue fever reported by Iwamoto (1973). In addition to these continuous reports of imported diseases, recent reports of cholera found in Arita city, Wakayama, and cholera patients found in Kobe who returned from on-board college gives us a warning that we, general practitioners, should be always on the alert of these facts in our day to day check-ups. The report of Kobari et al. (1973) on pest in Vietnam implies a possibility of other diseases imported and brings up problems of inspection, early discovery and treatment and prevention of the 2nd affection.

As we had an opportunity of examining 112 foreign patients from 33 countries visiting for job orientation at Matsushita Electric Co. Ltd. for 5 years from 1972 to 1976, we made a survey on medical records.

As shown in Table 4, visitors from A, B, C, D and E tropical regions showed 20.2 per cent of morbidity rate (98 out of 485 visitors), while visitors from the other regions showed 29.8 per cent (14 patients out of 47 visitors). Fortunately we did not find patients with protozoa diseases such as malaria and amebic dysentheria, bacterial diseases such as cholera, typhoid fever, and virus diseases such as dengue fever, smallpox and yellow fever. Unusual cases were patients with Tenia saginata and a case with orchitis due to mumps infected before coming to Japan. Exractum filicis was prescribed for the Tenia saginata patient to excrete helminth, and the orchitis patient was treated with antifebrile and intravenous infusion, antibiotics for protection from of the 2nd affection in the hospital, and both of them were cured.

Another significant finding of our research was the fact that many common cold patients were found among visitors from tropical regions. According to the monthly statistics, this shows different tendency from influenza prevalence in Japan and the visitors get affected in fall, especially in October and November quite different from the peak of influenza in Japan (Table 6). Moreover, most of them became sick after a few days of their arrival. There is an assumption that the reason for this fact is due to the difficulty in changing clothes and living customs, and slow adjustment to the new environment of their sweat gland to control body temperature, and fatigue as well as the fact that they are exposed to invasion of pathogenes into the respiratory tract on the visit to a completely different climate. Therefore, we understand that 
early treatment and orientation to Japanese environment, especially to clothes, are of vital importance as the preventive means for them who have had difficulty in using their medical facilities in their home countries. Although import of typical tropical diseases by foreign visitors was not found, there should be a possibility of missing some diseases, and our examinations at Health Consultation Room were not enough because checking points were blood test and stool examination only once.

We are convinced that the above mentioned two examinations are integral parts of prevention of imported tropical diseases when we, general practitioners, examine foreign patients in Japan.

\section{REFERENCES}

1) Aihara, M., Tajimi, H., Takahashi, H., Amano, H. and Yamamoto, T. (1976): Case of imported Salmonella paratyphi A, Jap. J. Trop. Med. Hyg., 4 (1), 62

2) Ebisawa, I., Kawamura, Z., Mitsuzawa, E., Komatsu, T., Nagashima, Y., Suzuki, H. and Hagihara, M. (1975): Critical condition of malaria, Jap. Med. J., 2690, 43-47

3) Ebisawa, I., Nakamura, S., Sugimoto, H. and Takigami, T. (1969): The recent malaria, Jap. Med. J., 2372, 11-17

4) Ebisawa, I. (1973): Imported malaria, Diag. Treat., 61 (7), 76-81

5) Ebisawa, I. (1973): Current problems of malaria, Tokyo. J. Med. Science., 81 (1), 56-67

6) Ebisawa, I., Muto, T., Nakamura, S., Komoriya, T. and Kimura, M. (1973): Analysis of 73 Malaria-patients, J. Jap. Assocat. Infect. Dis., 47 (11), 425-430

7) Hino, S. and Kawane, K. (1974): A clinical case of smallpox, Jap. Med. J., 2566, 22-26

8) Iwamoto, I. (1973): A case of imported dengue fever, Trop. Med., 15 (4), 225-230

9) Kamegai, S. (1976): The tapeworm diseases infected in the foreign countries, Jap. J. Trop. Med. Hyg., 4 (1), 55

10) Kobari, K. (1973): Imported infectious diseases, Infect. Inflamm. Imm. 4 (1), 1-7

11) Nakabayashi, T., Ohtomo, H., Ebisawa, I. and Ishizaki, T. (1975): The present situation of malaria, Inform. Pub. Hyg., 5 (9), 1-4

12) Sassa, M., Ebisawa, I. and Kanda, R. (1969): The tropical diseases, 1st ed., 1-26, Tokyo University International Edition, Tokyo

13) Tsubura, H., Tanaka, O., Ozaki, F., Ito, Y. and Fujii, H. (1973): A clinical case of imported malaria from Pl. vivax, Jap. J. Cln. Exp. Med., 50 (10), 92-98

14) Yamaguchi, K., Harada, T., Akamine, T. and Tsuneda, K. (1973): A clinical case of imported malaria from Pl. falciparum, Diag. Treat., 61 (7), 159-162

\section{某社来訪外国人の羅病に関する研究}

$$
\begin{gathered}
\text { 奥村 悦之 } 之^{1} \cdot \text { 中井 益代 } 2 \text { 三好 博文 }{ }^{2} \\
\text { 吉田 康久 }{ }^{3} \text { 豊田 秀三 }
\end{gathered}
$$

国外旅行者の数に比例して熱带性疾患に槛患するものの增加の傾向が, 最近の研究によって指摘さ

1 大阪医科大学第 2 内科学教室 2 大阪医科大学微生物学教室 3 大阪医科大学衛生学公俥衛生学 教室 
れている。乙の事実はまた，わが国を訪れ，特に一定期間滞在する外国人が熱带病病原体を移人し， 伝染源となり得る可能性を暗示するものである。我々はこの推定を検討するために1972年より1976年 に至る 5 年間，技術訓練のため熱帯諸国ならびに欧州，北米より松下電器産業株式会社への来訪者に ついて，一定期間の䍜病状況を診断または医学記録によって分析し，つぎの結果を得た。

1）総計532名の来訪者のうち485名が熱帯諸国より，また47名がその他諸国よりの来訪者で，その到 着時より 1 カ月間の罹病率はそれぞれ $20.2 \%, 29.8 \%$ あった。

2）今回の調査では幸いにも，マラリア，フィラリア，コレラ等の熱帯病は認められなかった。

3） 母国で感染し，来日に際して発病したマレーシア人の無鈎条虫症，イラン人の続発性睪丸炎各 1 例 が特記されるものであったほかは，感冒，胃腸炎，猿麻疹等一般的な疾患が多かった。

4）熱帯圈よりの来訪者は, 欧州, 北米等よりのそれに比較して, 特に秋, 冬期に到着後 $2 \sim 3$ 日以 内にかなり高率に感冒に愯患する傾向が認められた。

5）以上得られた成績は，外国人による熱带病移人の可能性の実態を明らかにするとともにまた， これら来訪者の健康管理上の資料として評価され得る。

6）㷌国邦人および外国人来訪者に対する，理解ある検款ならびに実地医家の，輸人熱带病について の良き認識は，今後ともこれら疾患の移人を防ぐ対策として不可欠である。 